Indonesian Journal of Cardiology

Indonesian J Cardiol 2019:40:206-215

pISSN: 0I 26-3773 / elSSN: 2620-4762

doi: 10.3070I/ijc.v40il.799

\title{
Correlation Between Serum Level Galectin-3 and Early Remodelling Indicator of Left Ventricle in Patient with Acute Myocardial Infarction During Pre-Percutaneous Coronary Intervention
}

\author{
I Nyoman Indrawan Mataram 1, Wayan Aryadana ${ }^{1}$, AA Wiradewi Lestari2
}

I Department of Cardiology and Vascular Medicine, Faculty of Medicine, Udayana University, Sanglah General Hospital,

2 Department of Clinical Pathology, Faculty of Medicine, Udayana University, Sanglah General Hospital

\section{Correspondence:} dr. I Nyoman Indrawan Mataram. Department of Cardiology and Vascular Medicine, Faculty of Medicine, Udayana University E-mail: indrawan4545@ yahoo.com

\begin{abstract}
Backgorund: Acute coronary syndrome (ACS) is a spectrum of coronary heart disease. Early remodelling process (within 0-72 hours) post infarction can be assessed by circulating biomarker (Galectin-3), echocardiography, coronary angiography, and clinically. The aim of study is to know the correlation between serum level of Galectin-3 and early remodelling indicator in patient with acute myocardial infarction during pre-percutaneous coronary intervention. The parameters are LVEDV, LVEF, diastolic function component, TIMI flow, $M B G$, and presence of acute heart failure.

Methods: This cross sectional study was conducted in Sanglah General Hospital during March-May 2018. A 62 sample was determined consecutively.

Results: Bivariate analysis with Spearman correlation shows Galectin-3 correlated with LVEDV $(r=0,808 ; p<0.001)$, E/e' average $(r=0,297 ; p=0,019)$, E/A ratio $(r=0,26$; $p=0,04 \mathrm{I})$, and MBG (QuBE) $(r=0,647 ; p<0.00 \mathrm{I})$. No correlation was found between Galectin-3 and LVEF Teich, LVEF Biplane, LAVI, e'septal, e'lateral, and TR Vmax. Chi square analysis shows no association between Galectin-3 and diastolic dysfunction left ventricle, TIMI flow, MBG score, and acute heart failure. Multivariate analysis with multiple linear regression shows an increase in Galectin-3 has been proven associated independently with LVEDV, LAVI, E/e' average, and E/A ratio. Multiple logistic regression shows Galectin-3 has not been proven independently with diastolic dysfunction, TIMI flow, MBG score, and acute heart failure. LVEDV is the best outcome that can be explained as its value influenced by constant, BMI, and Galectin-3 (R2 = 0,509).

Conclusion: Galectin-3 correlated with LVEDV, average E/e', E/A ratio, and MBG (QuBE). There is an independent association between Galectin-3 and LVEDV, LAVI, average E/e, and E/A ratio. Early remodelling process within 0-72 hours post infarction was happened pre$\mathrm{PCl}$. Anti-remodelling (including anti failure) during early phase is strongly recommended in order to prevent worse outcome in short and long term.
\end{abstract}

(Indonesian J Cardiol. 2019;40:206-215)

Keywords: Galectin-3, early remodelling left ventricle, acute myocardial infarction, percutaneous coronary intervention. 


\title{
Korelasi Antara Kadar Serum Galectin-3 dan Indikator Early Remodelling Ventrikel Kiri pada Penderita Infark Miokard Akut sebelum Menjalani Tindakan Intervensi Koroner Perkutan
}

\author{
I Nyoman Indrawan Mataram 1, Wayan Aryadana1, AA Wiradewi Lestari2
}

\begin{abstract}
Abstrak
Latar Belakang: Sindroma koroner akut (SKA) merupakan salah satu spektrum PJK dengan remodelling ventrikel kiri salah satu komplikasinya. Proses early remodelling (dalam 0-72 jam) paska infark dapat dinilai dari pemeriksaan biomarka (Galectin-3), ekokardiografi, angiografi koroner, dan klinis. Oleh karena itu, penelitian ini bertujuan mengetahui korelasi antara kadar serum Galectin-3 dengan indikator early remodelling ventrikel kiri pada penderita IMA sebelum menjalani tindakan IKP. Parameter tersebut antara lain LVEDV, LVEF, komponen fungsi diastolik, TIMI flow, MBG, dan gagal jantung akut.

Metode: Penelitian menggunakan rancangan cross-sectional dan dilakukan di RSUP Sanglah selama periode Maret-Mei 2018. Sampel ditentukan secara consecutive hingga mencapai 62 sampel.

Hasil: Hasil analisis bivariat dengan Spearman correlation menunjukkan Galectin-3 berkorelasi dengan nilai LVEDV $(r=0,808 ; \mathrm{p}<0.001)$, rerata E/e' $(r=0,297 ; p=0,019)$, E/A ratio $(r=0,261 ; p=0,041)$, dan MBG (QuBE) $(r=0,674 ; p<0.001)$. Tidak terdapat korelasi antara Galectin-3 dan LVEF Teich, LVEF Biplane, LAVI, e’septal, e'lateral, dan TR Vmax. Uji chi square didapatkan tidak ada hubungan antara Galectin-3 dan disfungsi diastolik ventrikel kiri, TIMI flow, skor MBG, serta kejadian gagal jantung akut. Hasil analisis multivariat regresi linier berganda didapatkan peningkatan kadar Galectin-3 terbukti berhubungan secara independen dengan peningkatan LVEDV, LAVI, rerata E/e', dan E/A ratio. Regresi logistik berganda menunjukkan Galectin-3 tidak terbukti berhubungan secara independen terhadap terjadinya disfungsi diastolik, rendahnya TIMI flow dan skor MBG pre-IKP, dan kejadian gagal jantung akut. Nilai LVEDV merupakan outcome terbaik yang dapat dijelaskan dengan melibatkan konstanta, nilai Galectin-3, dan BMI (R2 = 0,509).

Kesimpulan: Galectin-3 berkorelasi dengan nilai LVEDV, rerata E/e', E/A ratio, dan MBG (QuBE). Galectin-3 berhubungan secara independen dengan nilai LVEDV, LAVI, rerata E/e', dan E/A ratio. Proses early remodelling terbukti berlangsung pada 0-72 jam paska IMA sebelum dilakukan tindakan IKP. Pemberian agen anti-remodelling (termasuk anti failure) pada fase awal IMA sangat direkomendasikan untuk mencegah outcome buruk baik itu jangka pendek maupun jangka panjang.
\end{abstract}

(Indonesian J Cardiol. 2019;40:206-215)

Keywords: Galectin-3, early remodelling left ventricle, acute myocardial infarction, percutaneous coronary intervention.

IDepartment of Cardiology and Vascular Medicine, Faculty of Medicine, Udayana University, Sanglah General Hospital,

2 Department of Clinical Pathology, Faculty of Medicine, Udayana University, Sanglah General Hospital

\section{Korespondensi:}

dr. I Nyoman Indrawan Mataram.

Department of Cardiology and Vascular Medicine,

Faculty of Medicine, Udayana University

E-mail: indrawan4545@yahoo.com

\section{Pendahuluan}

Tronary artery disease (CAD) atau penyakit arteri koroner yang selanjutnya dikenal sebagai penyakit jantung koroner (PJK) adalah satu satu penyakit kardiovaskular yang masih merupakan penyebab utama kematian di berbagai belahan dunia. Berdasarkan data dari World Heart Organization (WHO), sebanyak 7,3 juta kematian di 
seluruh dunia tiap tahunnya dikarenakan oleh penyakit jantung koroner (PJK). Infark miokard akut (IMA) atau yang sering disebut infark miokard merupakan salah satu komplikasi dari penyakit jantung koroner, yang termasuk ke dalam kelompok sindroma koroner akut (SKA) atau acute coronary syndrome (ACS). ${ }^{1}$

Penyakit jantung koroner juga merupakan salah satu penyakit yang tercatat pada kunjungan rawat jalan, unit gawat darurat, dan perawatan intensive cardiac care unit (ICCU) di Instalasi Pelayanan Jantung Terpadu (PJT) Rumah Sakit Umum Pusat (RSUP) Sanglah. Pada tahun 2015, PJK menempati urutan pertama (30\%) pada 10 kasus terbanyak kunjungan rawat jalan atau poliklinik, dan tetap menjadi yang terbanyak pada tahun 2016 (36\%). Infark miokard menempati urutan kedua pada 10 kasus terbanyak yang memerlukan perawatan di ICCU PJT RSUP Sanglah tahun 2015 (17\%) dan mengalami peningkatan menjadi urutan pertama pada tahun 2016 (34\%). Angka mortalitas infark miokard di RSUP Sanglah masih tinggi. Sebanyak 60\% kasus kematian di ICCU PJT RSUP Sanglah tahun 2016 dikarenakan IMA dan komplikasi terkaitnya.

Salah satu kejadian kardiovaskular mayor atau adverse outcome pada IMA yang terkait dengan proses remodelling ventrikel kiri adalah gagal jantung.,2,3 Terjadinya remodelling ventrikel kiri merupakan determinan kesintasan yang utama pada penderita paska infark. Hal ini diperkuat dari banyak hasil studi yang mengemukakan hubungan yang signifikan dengan outcome klinis penderita. ${ }^{2}$ Proses terjadinya remodelling ventrikel kiri yang terjadi pada penderita infark dapat dideteksi dari kondisi klinis dan berbagai macam modalitas pemeriksaan. Secara klinis, salah satu kondisi yang erat kaitannya dengan proses remodelling ventrikel kiri adalah gagal jantung kongesti. Beberapa parameter ekokardiografi transtorakal yang digunakan untuk menilai adanya remodelling ventrikel antara lain perubahan dimensi jantung berupa dilatasi ventrikel kiri (adanya peningkatan left ventriclular end diastolic diameter atau LVEDD, peningkatan left ventricular end diastolic volume atau LVEDV) dan gangguan fungsi sistolik maupun diastolik ventrikel kiri. Beberapa parameter pemeriksaan angiografi koroner diyakini berhubungan sebagai penanda atau prediktor terjadinya remodelling itu sendiri, seperti rendahnya skor Thrombolysis in Myocardial Infarction (TIMI) flow baik itu pre dan paska revaskularisasi, rendahnya myocardial blush grade (MBG), luasnya area infark, tidak adanya pembuluh darah kolateral, dan disertai adanya dilatasi ventrikel kiri melalui ventrikulografi. ${ }^{1}$ Biomarka yang terlibat dalam proses remodelling ventrikel kiri fase dini atau early adalah Galectin-3. Walaupun sudah cukup banyak makalah yang menyatakan peranan Galectin-3 dalam proses remodelling dan sebagai faktor prognostik pada penderita gagal jantung, namun, belum ada studi yang mengaitkan hubungan antara kadar Galectin-3 dalam serum dan indikator atau penanda early remodelling ventrikel kiri pada IMA. Hal ini penting karena early remodelling merupakan proses paling awal yang terjadi pada periode paska infark dan di satu sisi dengan adanya tindakan IKP diasumsikan mempengaruhi proses remodelling tersebut.

Berdasarkan paparan latar belakang di atas, penulis ingin meneliti tentang korelasi antara kadar serum Galectin-3 dengan indikator early remodelling ventrikel kiri pada penderita IMA sebelum menjalani tindakan IKP.

\section{Metode}

Penelitian ini merupakan penelitian analitik cross sectional dengan uji korelasi. Pengambilan sampel Galectin-3 dilakukan di UGD RSUP Sanglah saat awal kedatangan penderita. Kemudian dilakukan penilaian indikator early remodelling ventrikel kiri, berupa pengamatan adanya kejadian gagal jantung akut saat kedatangan penderita, pengukuran parameter LVEDV, LVEF, dan fungsi diastolik ventrikel kiri melalui pemeriksaan ekokardiografi, serta penilaian skor TIMI flow dan MBG dari angiografi koroner sebelum dilakukan tindakan IKP. Lokasi dan waktu penelitian ini adalah di instalasi gawat darurat (UGD) dan ruang perawatan RSUP Sanglah-Denpasar, yang dilaksanakan sejak bulan Maret 2018 sampai jumlah sampel tercapai. Sampel penelitian adalah penderita infark miokard akut yang masuk populasi terjangkau yang memenuhi kriteria inklusi dan tidak memenuhi kriteria eksklusi. Subyek diambil dengan cara consecutive sampling dari populasi penelitian dan bersedia ikut serta dalam penelitian. Kriteria inklusi adalah

Semua penderita infark miokard akut berusia 18 tahun ke atas yang masuk melalui UGD RSUP Sanglah Denpasar dan bersedia ikut dalam penelitian dan menandatangani informed consent. Kriteria eksklusi meliputi, riwayat IMA dalam 3 bulan terakhir, stroke/ 
Tabel 1 Karakteristik subyek IMA yang menjalani pemeriksaan Galectin-3, ekokardiografi, dan angiografi pre-tindakan IKP $(\mathrm{n}=62)$

\begin{tabular}{|c|c|c|c|c|c|}
\hline \multirow{3}{*}{\multicolumn{3}{|c|}{$\begin{array}{l}\text { Galectin-3, ekokardiografi, dan angiografi pre-tindakan IKP } \\
(\mathrm{n}=62)\end{array}$}} & \multicolumn{3}{|l|}{ Gagal jantung, n (\%) } \\
\hline & & & $\mathrm{Ya}$ & $6(10)$ & $28(45)$ \\
\hline & & & Tidak & $2(3)$ & $26(42)$ \\
\hline \multirow[t]{2}{*}{ Variabel } & \multirow{2}{*}{$\begin{array}{c}\text { Galectin-3< } \\
7,67 \mathrm{ng} / \mathrm{ml}\end{array}$} & \multirow{2}{*}{$\begin{array}{l}\text { Galectin-3 } \geq \\
7,67 \mathrm{ng} / \mathrm{ml} \\
\end{array}$} & Diagnosis & & \\
\hline & & & STEMI, n (\%) & $7(11)$ & $48(77)$ \\
\hline \multicolumn{3}{|l|}{ Demografi } & NSTEMI, n (\%) & $1(2)$ & $6(10)$ \\
\hline Usia (tahun), rerata $\pm \mathrm{SB}$ & $56 \pm 4$ & $57 \pm 2$ & \multicolumn{3}{|l|}{ Biomarka remodelling } \\
\hline \multicolumn{3}{|l|}{ Usia (tahun), n (\%) } & Galectin-3, rerata $\pm S B$ & $6 \pm 0$ & $19 \pm 0$ \\
\hline$<30$ & $0(0)$ & $1(2)$ & \multicolumn{3}{|l|}{ Ekokardiografi } \\
\hline $30-49$ & $4(7)$ & $10(16)$ & LVEDV, rerata $\pm S B$ & $50 \pm 3$ & $96 \pm 4$ \\
\hline $50-69$ & $3(5)$ & $36(58)$ & LVEF Teich, rerata \pm SB & $53 \pm 3$ & $52 \pm 1$ \\
\hline$\geq 70$ & $1(2)$ & $7(11)$ & LVEF Biplane, rerata \pm SB & $54 \pm 4$ & $51 \pm 1$ \\
\hline \multicolumn{3}{|l|}{ Jenis kelamin, n (\%) } & LAVI, rerata $\pm S B$ & $15 \pm 2$ & $14 \pm 1$ \\
\hline Lelaki & $10(16)$ & $45(73)$ & e' septal, rerata $\pm S B$ & $7 \pm 1$ & $7 \pm 0$ \\
\hline Perempuan & $1(2)$ & $6(10)$ & e' lateral, rerata $\pm S B$ & $8 \pm 1$ & $8 \pm 0$ \\
\hline Suku, n (\%) & & & Rerata E/e', rerata $\pm \mathrm{SB}$ & $9 \pm 1$ & $10 \pm 1$ \\
\hline Bali & $5(8)$ & $44(71)$ & $\mathrm{E} / \mathrm{A}$ ratio, rerata $\pm \mathrm{SB}$ & $1 \pm 0$ & $1 \pm 1$ \\
\hline Jawa & $2(3)$ & $8(13)$ & $\mathrm{TR} V \max$, rerata $\pm \mathrm{SB}$ & $1 \pm 0$ & $2 \pm 0$ \\
\hline Lainnya & $1(2)$ & $2(3)$ & \multicolumn{3}{|l|}{ Diastolic dysfunction, n (\%) } \\
\hline BMI $(\mathrm{kg} / \mathrm{m} 2)$, rerata $\pm \mathrm{SB}$ & $26 \pm 1$ & $25 \pm 0$ & Normal & $2(3)$ & $10(16)$ \\
\hline \multicolumn{3}{|l|}{ BMI $(\mathrm{kg} / \mathrm{m} 2), \mathrm{n}(\%)$} & Grade I & $4(7)$ & $27(43)$ \\
\hline Underweight & $0(0)$ & $1(2)$ & Grade II & $2(3)$ & $13(21)$ \\
\hline Normal & $4(7)$ & $34(55)$ & Grade III & $0(0)$ & $4(7)$ \\
\hline Overweight & $3(5)$ & $16(26)$ & Angiografi & & \\
\hline Obese & $1(2)$ & $3(5)$ & Kompleksitas lesi koroner, $\mathrm{n}$ & & \\
\hline \multicolumn{3}{|l|}{ Riwayat CHF, n (\%) } & $(\%)$ & $3(5)$ & $15(24)$ \\
\hline Ya & $2(3)$ & $9(15)$ & $1 \mathrm{VD}$ & $3(5)$ & $17(27)$ \\
\hline Tidak & $9(15)$ & $42(68)$ & $2 \mathrm{VD}$ & $2(3)$ & $18(29)$ \\
\hline \multicolumn{3}{|l|}{ Riwayat obat anti-failure } & $3 \mathrm{VD}$ & $0(0)$ & $4(7)$ \\
\hline \multicolumn{3}{|l|}{ (ACE-I, ARB, MRA), n (\%) } & \multicolumn{3}{|l|}{ Left Main Disease } \\
\hline $\mathrm{Ya}$ & $2(3)$ & $6(10)$ & IRA, n (\%) & & \\
\hline Tidak & $9(15)$ & $45(73)$ & $\mathrm{LAD}$ & $3(5)$ & $41(66)$ \\
\hline \multicolumn{3}{|l|}{ Riwayat HT, n (\%) } & $\mathrm{LCx}$ & $1(2)$ & $4(7)$ \\
\hline $\mathrm{Ya}$ & $4(7)$ & $23(37)$ & RCA & $4(7)$ & $9(15)$ \\
\hline Tidak & $7(11)$ & $28(45)$ & LM & $0(0)$ & $0(0)$ \\
\hline Riwayat DM, n (\%) & & & $\mathrm{MBG}(\mathrm{QuBE})$, rerata $\pm \mathrm{SB}$ & $3 \pm 0$ & $9 \pm 0$ \\
\hline Ya & $4(7)$ & $14(23)$ & MBG (score), n (\%) & & \\
\hline Tidak & $7(11)$ & $37(60)$ & 0 & $1(2)$ & $1(2)$ \\
\hline Riwayat merokok, n (\%) & & & 1 & $7(11)$ & $38(61)$ \\
\hline Ya & $4(6)$ & $33(53)$ & 2 & $0(0)$ & $14(23)$ \\
\hline Tidak & $4(7)$ & $21(34)$ & 3 & $0(0)$ & $1(2)$ \\
\hline Klinis & & & TIMI flow pre-IKP, n (\%) & & \\
\hline Onset nyeri dada (jam), rerata & $6 \pm 1$ & $8 \pm 1$ & 0 & $2(3)$ & $21(34)$ \\
\hline$\pm \mathrm{SB}$ & & & 1 & $1(2)$ & $4(7)$ \\
\hline & & & 2 & $3(5)$ & $11(18)$ \\
\hline & & & 3 & $2(3)$ & $18(29)$ \\
\hline
\end{tabular}


Indonesian Journal of Cardiology

Tabel 2 Reliabilitas parameter ekokardiografi

\begin{tabular}{|c|c|c|c|c|c|c|c|}
\hline \multirow{3}{*}{ Variabel } & \multirow{3}{*}{$\underset{\text { (2-tailed) }}{\mathrm{p}}$} & \multicolumn{3}{|c|}{ Test value $=0$} & \multirow{3}{*}{ SB } & \multirow{2}{*}{\multicolumn{2}{|c|}{ Limit of agreement }} \\
\hline & & \multirow{2}{*}{$\begin{array}{c}\text { Mean } \\
\text { differences }\end{array}$} & \multicolumn{2}{|c|}{ IK 95\% } & & & \\
\hline & & & Lower & Upper & & Min & Maks \\
\hline Selisih LVEDV & 0,753 & 0,080 & $-0,430$ & 0,590 & 2,009 & $-3,850$ & 4,010 \\
\hline Selisih LVEF Teich & 0,318 & 0,350 & $-0,345$ & 1,045 & 2,738 & $-6,265$ & 5,574 \\
\hline Selisih LVEF Biplane & 0,468 & 0,2209 & $-0,384$ & 0,826 & 2,383 & -4.980 & 4,220 \\
\hline Selisih LAVI & $<0.001$ & $-1,300$ & $-1,375$ & $-0,864$ & 1,716 & $-4,735$ & 1,985 \\
\hline Selisih e'septal & 0,093 & 0,181 & $-0,312$ & 0,393 & 0,834 & $-1,420$ & 1,780 \\
\hline Selisih e’lateral & 0,074 & $-0,258$ & $-0,542$ & 0,026 & 1,117 & $-2,598$ & 2,082 \\
\hline Selisih E/e' rerata & 0,681 & 0,091 & $-0,348$ & 0,530 & 1,729 & $-3,289$ & 3,471 \\
\hline Selisih E/A Ratio & 0,373 & $-0,13$ & $-0,420$ & 0,159 & 1,140 & $-2,410$ & 2,150 \\
\hline Selisih TR Vmax & 0,350 & $-0,081$ & $-0,253$ & 0,091 & 0,678 & $-1,431$ & 1,269 \\
\hline
\end{tabular}

Tabel 3 Analisis bivariat variabel numerik dengan signifikansi 2 arah (spearman)

\begin{tabular}{|c|c|}
\hline Variabel & Galectin-3 \\
\hline \multirow{2}{*}{ LVEDV } & $\mathrm{r}=0,808$ \\
\hline & $\mathrm{p}<0.001$ \\
\hline \multirow{2}{*}{ LVEF Teich } & $r=-0,213$ \\
\hline & $\mathrm{p}=0,097$ \\
\hline \multirow{2}{*}{ LVEF Biplane } & $r=-0,226$ \\
\hline & $\mathrm{p}=0,077$ \\
\hline \multirow{2}{*}{ LAVI } & $\mathrm{r}=0,301$ \\
\hline & $\mathrm{p}=0,170$ \\
\hline \multirow{2}{*}{ e’septal } & $\mathrm{r}=-0,079$ \\
\hline & $\mathrm{p}=0,539$ \\
\hline \multirow{2}{*}{ e'lateral } & $r=-0,092$ \\
\hline & $p=0,476$ \\
\hline \multirow{2}{*}{ Rerata E/e' } & $r=0,297$ \\
\hline & $\mathrm{p}=0,019$ \\
\hline \multirow{2}{*}{ E/A ratio } & $r=0,261$ \\
\hline & $\mathrm{p}=0,041$ \\
\hline \multirow{2}{*}{ TR Vmax } & $r=0,068$ \\
\hline & $p=0,600$ \\
\hline \multirow{2}{*}{ MBG (QuBE) } & $r=0,674$ \\
\hline & $\mathrm{p}<0.001$ \\
\hline
\end{tabular}

transient ischemic attack (TIA) dalam 1 tahun terakhir, keganasan, sepsis, anemia, penyakit ginjal kronik, sirosis hepatis, dan systemic lupus eryhthematosus (SLE). Besar sampel didapatkan 62 orang. Variabel tergantung adalah LVEDV, LVEF, fungsi diastolik ventrikel kiri, TIMI flow, MBG, dan kejadian gagal jantung akut. Variabel bebas adalah kadar serum Galectin-3. Variabel kendali adalah usia, jenis kelamin, BMI, DM, HT, CHF, dan penggunaan obat-obatan ACE-I, ARB, dan MRA. Analisis data dilakukan dengan program IBM Statistical Package for the Social Science (SPSS) Statistic seri 23.

\section{Hasil}

Karakteristik demografi, klinis, laboratorium, ekokardiografi, dan angiografi penderita dikelompokkan menjadi dua, yaitu kelompok dengan kadar Galectin-3 yang normal $(<7,67 \mathrm{ng} / \mathrm{ml})$ dan kelompok dengan kadar Galectin-3 yang tinggi $(\geq 7,67 \mathrm{ng} / \mathrm{ml})$.

Parameter ekokardiografi pada penelitian ini diukur oleh dua orang observer. Oleh karena itu, diperlukan uji komparatif kesesuaian baik itu untuk variabel numerik maupun katagorikal.

Uji komparatif kesesuaian variabel derajat disfungsi diastolik (katagorikal) menggunakan uji kappa. Dari hasil analisis, sebanyak 100\% hasil pengukuran menunjukkan hasil yang sama (sel konkordan), uji kappa didapatkan nilai 1,0 (dari minimal 0,8), p<0,001. $\mathrm{Hal}$ ini berarti kedua observer memiliki penilaian yang sama pada seluruh sampel.

Dari tabel diatas didapatkan, analisis bivariat menunjukkan Galectin-3 berkorelasi kuat dengan $\operatorname{LVEDV}(\mathrm{r}=0,808 ; \mathrm{p}<0.001)$, berkorelasi lemah dengan rerata $E / e^{\prime}(r=0,297 ; p=0,019)$ dan $E / A$ ratio $(r=0,261$; $\mathrm{p}=0,041)$, dan berkorelasi sedang dengan MBG (QuBE) $(\mathrm{r}=0,674 ; \mathrm{p}<0.001)$. Semua arah korelasi positif dan dua arah. 
Indonesian Journal of Cardiology

Tabel 4 Analisis bivariat variabel katagorikal (chi square)

\begin{tabular}{ccccc}
\hline Variabel & Derajat disfungsi diastolik & TIMI Flow & Skor MBG & Gagal jantung akut \\
Galectin-3 & $\mathrm{OR}=1,096 \mathrm{p}=0,902$ & $\mathrm{OR}=1,556 \mathrm{p}=0,518$ & $\mathrm{OR}=0,246 \mathrm{p}=0,197$ & $\mathrm{OR}=0,774 \mathrm{p}=0,702$ \\
\hline
\end{tabular}

Tabel 5 Hasil analisis regresi linier

\begin{tabular}{|c|c|c|c|c|c|c|c|}
\hline \multirow{2}{*}{ Variabel } & \multirow{2}{*}{$\mathrm{R}$} & \multirow{2}{*}{$\mathrm{R}^{2}$} & \multirow{2}{*}{ Adjusted $\mathrm{R}^{2}$} & \multirow{2}{*}{$\begin{array}{c}\text { Koefisien } \\
\text { Regresi (B) }\end{array}$} & \multirow{2}{*}{ Nilai p } & \multicolumn{2}{|c|}{ IK 95\% } \\
\hline & & & & & & Bawah & Atas \\
\hline \multicolumn{8}{|l|}{ LVEDV } \\
\hline Model B & 0,714 & 0,509 & 0,493 & & & & \\
\hline Konstanta & & & & 86,593 & 0,005 & 27,657 & 145,528 \\
\hline BMI & & & & $-2,568$ & 0,019 & $-4,690$ & $-0,446$ \\
\hline Galectin-3 & & & & 3,930 & $<0.001$ & 2,811 & 5,049 \\
\hline \multicolumn{8}{|l|}{ LVEF Teich } \\
\hline Model C & 0,310 & 0,096 & 0,081 & & & & \\
\hline Konstanta & & & & 68,050 & $<0.001$ & 55,166 & 80,934 \\
\hline Usia & & & & $-0,281$ & 0,014 & -0503 & $-0,058$ \\
\hline \multicolumn{8}{|l|}{ LVEF Biplane } \\
\hline Model D & $<0.001$ & $<0.001$ & $<0.001$ & & & & \\
\hline Konstanta & & & & 51,002 & $<0.001$ & 48,551 & 53,454 \\
\hline \multicolumn{8}{|l|}{ LAVI } \\
\hline Model B & 0,389 & 0,151 & 0,122 & & & & \\
\hline Konstanta & & & & 0,909 & 0,901 & $-13,701$ & 15,518 \\
\hline Usia & & & & 0,237 & 0,038 & 0,013 & 0,461 \\
\hline Galectin-3 & & & & 0,509 & 0,023 & 0,073 & 0,944 \\
\hline \multicolumn{8}{|l|}{ e'septal } \\
\hline Model B & 0,496 & 0,246 & 0,220 & & & & \\
\hline Konstanta & & & & 5,430 & 0,031 & 0,511 & 10,349 \\
\hline Usia & & & & $-0,045$ & 0,021 & $-0,083$ & 0,007 \\
\hline BMI & & & & 0,150 & 0,037 & $-0,010$ & 0,291 \\
\hline \multicolumn{8}{|l|}{ e'lateral } \\
\hline Model C & 0,385 & 0,148 & 0,134 & & & & \\
\hline Konstanta & & & & 12,228 & $<0.001$ & 9,533 & 14,924 \\
\hline Usia & & & & $-0,075$ & 0,002 & $-0,122$ & $-0,029$ \\
\hline \multicolumn{8}{|l|}{ Rerata } \\
\hline E/e & 0,389 & 0,152 & 0,123 & & & & \\
\hline Model B & & & & 17,150 & $<0.001$ & 8,815 & 25,485 \\
\hline Konstanta & & & & $-0,360$ & 0,020 & $-0,660$ & 0,060 \\
\hline BMI & & & & 0,145 & 0,072 & $-0,014$ & 0,303 \\
\hline \multicolumn{8}{|l|}{ Galectin-3 } \\
\hline \multicolumn{8}{|l|}{ E/A Ratio } \\
\hline Model B & 0,339 & 0,115 & 0,085 & & & & \\
\hline Konstanta & & & & 1,630 & 0,003 & 0,573 & 2,687 \\
\hline Usia & & & & $-0,016$ & 0,047 & $-0,033$ & $<0.001$ \\
\hline Galectin-3 & & & & 0,031 & 0,052 & $<0.001$ & 0,063 \\
\hline \multicolumn{8}{|l|}{ TR Vmax } \\
\hline Model C & 0,334 & 0,111 & 0,097 & & & & \\
\hline Konstanta & & & & 4,671 & $<0.001$ & 2,342 & 7,000 \\
\hline BMI & & & & $-0,128$ & 0,008 & $-0,221$ & $-0,035$ \\
\hline \multicolumn{8}{|l|}{ MBG (QuBE) } \\
\hline Model C & 0,663 & 0,439 & 0,430 & & & & \\
\hline Konstanta & & & & 0,199 & 0,866 & $-2,142$ & 2,540 \\
\hline Galectin-3 & & & & 0,445 & $<0.001$ & 0,315 & 0,575 \\
\hline
\end{tabular}


Dari tabel di atas didapatkan Galectin-3 tidak berhubungan dengan derajat disfungsi diastolik $(\mathrm{OR}=$ 1,096; $\mathrm{p}=0$,902), TIMI flow (OR=1,556; $\mathrm{p}=0,518)$, skor $\mathrm{MBG}(\mathrm{OR}=0,246 ; \mathrm{p}=0,197)$, dan gagal jantung akut $(\mathrm{OR}=0,774 ; \mathrm{p}=0,702)$.

Dari keseluruhan model, nilai LVEDV yang paling dapat mencerminkan atau menjelaskan indikator early remodelling. Nilai $\mathrm{R}^{2}$ (koefisien determinasi) sebesar 0,509 berarti BMI dan Galectin-3 dapat menjelaskan 50,9\% nilai LVEDV, sedangkan sisanya sebesar 49,1\% dijelaskan oleh variabel lain yang tidak diketahui atau tidak diteliti. Persamaan nilai LVEDV $=86,593-2,568$ x BMI + 3,930 x Galectin-3.

Dari tabel diatas didapatkan hasil, tidak ada variabel yang berpengaruh terhadap fungsi diastolik ventrikel kiri. DM tidak berpengaruh terhadap TIMI flow $(\mathrm{OR}=$ 2,848, $\mathrm{p}=0,085)$. CHF berpengaruh terhadap skor MBG dan bermakna secara statistik $(\mathrm{OR}=5,600, \mathrm{p}=$ 0,015). CHF tidak berpengaruh terhadap kejadian gagal jantung akut $(\mathrm{OR}=0,312, \mathrm{p}=0,092)$. Sehingga disimpulkan, CHF berhubungan secara independen terhadap skor MBG.

\section{Diskusi}

Data deskriptif penelitian ini disajikan dalam dua kelompok, yaitu kelompok Galectin-3 yang tinggi dan normal. Hal ini mengacu pada penelitian oleh Tsay dkk yang menghasilkan cut-off kadar Galectin-3 sebesar 7,67 ng/ml dengan IMA sebagai outcome. Penelitian oleh Tsay ini juga memberikan nilai cut-off yang terbaik (sensitivitas 74,5\% dan spesifisitas 72,4\%) dibandingkan beberapa penelitian lainnya dengan nilai AUC 0,783. ${ }^{4}$ Pada penelitian ini didapatkan kelompok usia yang dominan terkena infark adalah 30-49 tahun (kelompok Galectin-3 normal) dan 50-69 tahun (kelompok Galectin-3 tinggi). Hal ini menunjukkan bahwa kisaran usia penderita IMA cenderung mengenai yang lebih muda. Subyek penelitian dominan suku Bali pada masing-masing kelompok. Subyek penelitian dominan memiliki katagori BMI normal. Subyek penelitian dominan memiliki riwayat DM dan HT. Pada kelompok Galectin-3 normal, subyek dominan bukan perokok, sedangkan pada kelompok Galectin-3 tinggi dominan adalah perokok. Hal ini sesuai teori bahwa DM, HT, dan perokok merupakan faktor risiko terjadinya IMA. ${ }^{5}$ Subyek penelitian mengalami nyeri dada dengan rerata onset hingga kedatangan 6-8 jam, hal ini menunjukkan sebagian besar subyek memiliki indikasi dilakukan tindakan revaskularisasi. Subyek penelitian pada kedua kelompok dominan mengalami STEMI. Terjadi peningkatan LVEDV, penurunan LVEF Teich dan Biplane, peningkatan LAVI, penurunan e'septal dan e'lateral, peningkatan rerata $E / e$, abnormalitas E/A ratio $(<1$ dan $>2)$ pada sebagian besar subyek dan kedua kelompok dominan mengalami disfungsi diastolik derajat I. Semua hal tersebut sesuai teori bahwa pada kisaran waktu 0-72 jam setelah IMA, proses early remodelling telah berlangsung. Hal

Tabel 6 Hasil analisis regresi logistik

\begin{tabular}{|c|c|c|c|c|c|c|c|c|}
\hline \multirow{2}{*}{ Variabel } & \multirow{2}{*}{ Koefisien } & \multirow{2}{*}{ S.E } & \multirow{2}{*}{ Wald } & \multirow{2}{*}{$\mathrm{df}$} & \multirow{2}{*}{$\mathrm{p}$-value } & \multirow{2}{*}{ OR } & \multicolumn{2}{|c|}{ IK $95 \%$} \\
\hline & & & & & & & Bawah & Atas \\
\hline \multirow{3}{*}{\multicolumn{9}{|c|}{$\begin{array}{l}\text { Derajat disfungsi diastolik } \\
\text { Step } 7 \\
\text { Konstanta }\end{array}$}} \\
\hline & & & & & & & & \\
\hline & & & & & & & & \\
\hline & 1,056 & 0,290 & 13,239 & 1 & $<0.001$ & 2,875 & - & - \\
\hline \multicolumn{9}{|l|}{ TIMI flow } \\
\hline \multicolumn{9}{|l|}{ Step 6} \\
\hline $\mathrm{DM}$ & 1,046 & 0,607 & 2,976 & 1 & 0,085 & 2,848 & 0,867 & 9,351 \\
\hline Konstanta & $-0,956$ & 0,526 & 3,297 & 1 & 0,069 & 0,385 & - & - \\
\hline \multicolumn{9}{|l|}{ Skor MBG } \\
\hline \multicolumn{9}{|l|}{ Step 5} \\
\hline Riwayat CHF & 1,723 & 0,708 & 5,917 & 1 & 0,015 & 5,600 & 1,397 & 22,441 \\
\hline Konstanta & $-0,182$ & 0,606 & 0,091 & 1 & 0,763 & 0,833 & - & - \\
\hline \multicolumn{9}{|l|}{ Gagal jantung akut } \\
\hline Step 5 & $-1,166$ & 0,692 & 2,839 & & & & & \\
\hline Riwayat CHF & 0,560 & 0,627 & 0,797 & 1 & 0,092 & 0,312 & 0,080 & 1,210 \\
\hline Konstanta & & & & 1 & 0,372 & 1,750 & - & - \\
\hline
\end{tabular}


ini ditunjukkan dengan perubahan struktur geometri dan fungsi dari ventrikel kiri secara obyektif. ${ }^{6}$ Data angiografi menunjukkan bahwa kelompok Galectin-3 yang tinggi memiliki kompleksitas lesi 3VD. Hal ini sesuai teori bahwa kompleksitas lesi merupakan salah satu prediktor terjadinya remodelling ventrikel kiri baik itu jangka pendek maupun panjang. Namun, korelasi diantaranya tidak dianalisis pada penelitian ini. Kedua kelompok, terutama kelompok Galectin-3 tinggi dominan memiliki nilai TIMI flow dan MBG yang rendah pre-tindakan. Hal ini sesuai dengan teori bahwa kedua parameter tersebut merupakan prediktor terjadinya remodelling ventrikel kiri. ${ }^{7}$

Didapatkan korelasi yang kuat dengan arah hubungan positif antara Galectin-3 dan LVEDV ( $\mathrm{r}=$ 0,808; $\mathrm{p}<0.001)$. Hal ini konsisten dengan penelitian Frunza dkk yang mendapatkan korelasi yang kuat antara LVEDP dan LVEDV dengan kadar Galectin-3. Korelasi bersifat linier $(r=0,67 ; p=0,033) .{ }^{8}$ Sanchiz dkk menyatakan bahwa nilai baseline LVEDV yang tinggi (> $90 \mathrm{ml} / \mathrm{m}^{2}$ ) pada penderita infark merupakan prediktor yang kuat terjadinya remodelling pada fase awal ( $\mathrm{p}$ $<0,002) .{ }^{9}$ Tidak didapatkan korelasi antara Galectin-3 dan LVEF, baik itu dengan metode Teich $(\mathrm{r}=-0,213$; $\mathrm{p}=$ 0,097) maupun Biplane $(\mathrm{r}=-0,226 ; \mathrm{p}=0,077)$. Teori atau studi terkait yang membahas korelasi ini masih conflicting. Studi oleh Hamdy dkk mengemukakan bahwa LVEF merupakan prediktor terjadinya remodelling ventrikel kiri baik itu pada populasi paska IMA maupun gagal jantung (Hamdy dkk., 2014). Terdapat korelasi negatif yang kuat antara keduanya (semakin rendah nilai EF, semakin tinggi nilai Galectin-3). Namun studi yang dilakukan oleh Weir dkk mendapatkan hasil yang serupa dengan penelitian ini. Asumsinya bahwa Galectin-3 lebih berpengaruh atau berkorelasi pada kondisi EF yang masih relatif baik (preserved EF) baik itu pada populasi IMA ataupun gagal jantung. Pada penelitian ini sebagian besar penderita memiliki nilai EF yang rendah. ${ }^{10}$ Terdapat korelasi antara Galectin-3 dan rerata E/e' serta E/A ratio. Hal ini sesuai dengan teori bahwa, komponen parameter fungsi diastolik berkorelasi dengan Galectin-3. Kedua parameter tersebut menandakan tekanan pengisian ventrikel kiri yang meningkat paska IMA yang diikuti peningkatan kadar Galectin-3. Cerisano dkk menyatakan bahwa E/e' merupakan prediktor terkuat early remodelling paska infark $\left(\mathrm{p}<0\right.$,0013). ${ }^{11}$ Korelasi antara Galectin-3 dan parameter fungsi diastolik lainnya belum dilaporkan dalam beberapa studi, namun jika dengan biomarka remodelling lainnya (NT-pro BNP dan kopeptin), rerata E/e' juga menunjukkan korelasi yang kuat. ${ }^{12}$ Tidak ada korelasi antara Galectin-3 dan LAVI, e'septal, e'lateral, dan TR Vmax, dan derajat disfungsi diastolik. Belum ada studi acuan yang menganalisis korelasi antara parameter tersebut secara spesifik. Tidak ada hubungan antara Galectin-3 dan TIMI flow pada penderita IMA pre IKP $(\mathrm{OR}=1,032, \mathrm{p}=0,966$, IK95\%=0,2394,462). Secara teori, rendahnya TIMI flow merupakan prediktor terjadinya remodelling ventrikel kiri jangka panjang. Penelitian yang dilakukan oleh Wita dkk juga menyimpulkan bahwa skor TIMI paska IKP yang berkorelasi secara signifikan terhadap proses remodelling ventrikel 6 bulan paska follow up dibanding pre IKP. Morishima dkk menyatakan bahwa, kelompok studi yang mengalami no reflow phenomenon (skor TIMI 0-1) paska PCI berhubungan dengan kejadian gagal jantung yang lebih besar pada saat periode follow-up (p $<0,001$ ) dan remodelling ventrikel. Asumsinya adalah penelitian ini menggunakan TIMI flow pre-IKP dan tidak menganalisis atau membandingkan dengan TIMI flow paska IKP, ataupun korelasinya dengan Galectin-3 dalam jangka panjang. Studi yang dikemukakan oleh Hamdy dkk dan Zornoff bahwa perbaikan TIMI flow paska IKP berhubungan dengan efek remodeling yang lebih rendah. Ada korelasi positif kuat antara Galectin-3 dan MBG (QuBE) pre IKP ( $\mathrm{r}=0,674 ; \mathrm{p}<0.001)$. Tidak ada hubungan antara Galectin-3 dan skor MBG pre IKP $(\mathrm{OR}=0,264, \mathrm{p}=0,197$, IK95\%=0,0312,259). Korelasi nilai MBG (QuBE) secara kuantitatif sesuai dengan teori yaitu MBG merupakan prediktor terjadinya remodelling paska IMA. Studi oleh Tomasik dkk mengemukakan bahwa nilai QuBE yang rendah berkorelasi positif dengan skor MBG pada penderita IMA. Namun, belum ada studi terkait yang melaporkan korelasinya dengan Galectin-3. Tidak ada korelasi antara Galectin-3 dan kejadian gagal jantung akut $(\mathrm{OR}=0,577$, $p=0,476, \quad$ IK95\% $\%=0,127-2,617)$. Teori dan studi menyatakan bahwa Galectin-3 merupakan prediktor bermakna untuk terjadinya gagal jantung saat periode follow-up ( $>6$ bulan). Penelitian oleh Dong dkk mengemukakan bahwa, perubahan kadar Galectin-3 selama periode follow-up 6 bulan (dengan pengukuran secara serial) lebih sensitif dan akurat sebagai biomarka prognostik gagal jantung terutama pada penderita paska 
IMA. Setiap peningkatan $1 \mathrm{ng} / \mathrm{ml}$, diikuti dengan peningkatan risiko terjadinya mortalitas dan hosptalisasi akibat gagal jantung. Tsay juga mendapatkan korelasi yang bermakna antara Galectin-3 dan gagal jantung akut (berdasarkan Killip class) $(r=0,427, p<0,001)$ setelah pengamatan 30 hari paska infark. ${ }^{4}$ Tidak adanya korelasi antara parameter tersebut pada penelitian ini diasumsikan karena penilaian gagal jantung dilakukan saat kedatangan penderita (masih dalam kisaran 0-72 jam) dan beberapa kasus sudah mendapatkan penanganan awal terapi anti-failure.

Dari seluruh model pada analisis regresi, model terbaik yang dapat menjelaskan proses early remodelling adalah nilai LVEDV. Nilai LVEDV dapat dijelaskan dengan persamaan yang melibatkan nilai konstanta, BMI, dan kadar Galectin-3. Sesuai teori, kovariat dengan nilai $\mathrm{R}^{2}$ paling tinggi yang dipilih untuk menentukan atau menjelaskan outcome terbaik.

Adanya hubungan independen antara kovariat dan outcome cukup relevan dan hanya terbatas pada populasi penelitian ini. Tidak adanya hubungan yang independen dengan beberapa parameter diatas diasumsikan bahwa penilaian outcome hanya dilakukan pada satu waktu. Hubungan antara kadar Galectin-3 secara serial tidak dianalisis dengan outcome jangka panjang. Selain itu, belum ada studi acuan serupa yang dapat membandingkan secara spesifik hubungan kovariat dengan outcome penelitian ini.

\section{Kesimpulan}

Terdapat korelasi antara Galectin-3 dan LVEDV, rerata E/e', E/A ratio, dan MBG (QuBE) pada penderita IMA sebelum menjalani tindakan IKP. Tidak ada korelasi antara Galectin-3 dan LVEF Teich, LVEF Biplane, LAVI, e'septal, e'lateral, dan TR Vmax pada penderita IMA sebelum menjalani tindakan IKP. Tidak ada hubungan antara Galectin-3 dan disfungsi diastolik ventrikel kiri, TIMI flow, skor MBG, dan kejadian gagal jantung akut pada penderita IMA sebelum menjalani tindakan IKP. Peningkatan kadar Galectin-3 terbukti berhubungan secara independen dengan peningkatan LVEDV, LAVI, rerata E/e', dan E/A ratio. Galectin-3 tidak terbukti berhubungan secara independen terhadap disfungsi diastolik, rendahnya TIMI flow dan skor MBG pre-IKP, serta kejadian gagal jantung akut. Dari hasil penelitian diatas, implikasi klinis yang dapat disimpulkan adalah proses early remodelling terbukti berlangsung pada 0-72 jam paska IMA, selama belum dilakukan tindakan IKP. Walaupun tidak semua parameter remodelling menunjukkan korelasi, pemberian agen anti-remodelling (termasuk anti failure) pada fase awal IMA sangat direkomendasikan untuk mencegah outcome buruk baik itu jangka pendek maupun jangka panjang.

\section{Daftar Singkatan}

ACE-I: angiotensin converting enzyme-inhibitor ACS: acute coronary syndrome

ARB: angiotensin receptor blocker

AUC: area under curve

BMI: body mass index

CAD: coronary artery disease

CHD: coronary heart disease

DM: diabetes mellitus

HT: hipertensi

ICCU: intensive cardiac care unit

IMA: infark miokard akut

IK: interval kepercayaan

IKP: intervensi koroner perkutan

LAVI: left atrial volume index

LVEDP: left ventricular end diastolic pressure

LVEF: left ventricular ejection fraction

LVEDV: left ventricle end diastolic volume

MBG: myocardial blush grade

MRA: mineralocorticoid receptor antagonist

OR: odds ratio

PJK: penyakit jantung koroner

QuBE: Quantitative blush score evaluation

RSUP: rumah sakit umum pusat

SKA: sindroma koroner akut

STEMI: ST elevation myocardial infarction

TIA: transient ischemic attack

TIMI: thrombolysis in myocardial infarction

UGD: unit gawat darurat

WHO: world heart organization

\section{Persetujuan Etik}

Penelitian ini adalah hasil karya sendiri, dan semua sumber yang dikutip maupun dirujuk telah dinyatakan dengan benar dan lolos kaji etik. 


\section{Persetujuan Publikasi}

Semua pihak telah menyetujui publikasi penelitian ini.

\section{Konflik Kepentingan}

Tidak ada konflik kepentingan dalam pelaksanaan penelitian ini.

\section{Pendanaan}

Pendanaan penelitian ini berasal dari dana pribadi peneliti.

\section{Daftar Pustaka}

1. Reed, G.W., Rossi, J.E. and Cannon, C.P., 2017. Acute myocardial infarction. The Lancet, 389(10065), pp.197-210.

2. Meijers, W.C., van der Velde, A.R., Pascual-Figal, D.A. and de Boer, R.A., 2015. Galectin-3 and postmyocardial infarction cardiac remodeling. European journal of pharmacology, 763, pp.115-121.

3. Bivona, G., Bellia, C., Sasso, B.L., Agnello, L., Scazzone, C., Novo, G. and Ciaccio, M., 2016. Short-term Changes in Gal 3 Circulating Levels After Acute Myocardial Infarction. Archives of Medical Research, 47(7), pp.521-525.

4. Tsays, T.H., Sung, P.H., Chang, L.T., Sun, C.K., Yeh, K.H., Chung, S.Y., Chua, S., Chen, Y.L., Wu, C.J., Chang, H.W. and Ko, S.F., 2012. Value and level of Galectin-3 in acute myocardial infarction patients undergoing primary percutaneous coronary intervention. Journal of atherosclerosis and thrombosis, $19^{(12)}$, pp.1073-1082.

5. Ibanez, B., James, S., Agewall, S., Antunes, M.J., Bucciarelli-Ducci, C., Bueno, H., Caforio, A.L., Crea, F., Goudevenos, J.A., Halvorsen, S. and Hindricks, G., 2017. 2017 ESC Guidelines for the management of acute myocardial infarction in patients presenting with ST-segment elevation: The Task Force for the management of acute myocardial infarction in patients presenting with ST-segment elevation of the European Society of Cardiology (ESC). European heart journal, 39(2), pp.119-177.

6. Zornoff, L.A., Skali, H., Pfeffer, M.A., Sutton, M.S.J., Rouleau, J.L., Lamas, G.A., Plappert,
T., Rouleau, J.R., Moyé, L.A., Lewis, S.J. and Braunwald, E., 2002. Right ventricular dysfunction and risk of heart failure and mortality after myocardial infarction. Journal of the American College of Cardiology, 39(9), pp.1450-1455.

7. Gibson, C. M., \& Schömig, A. (2004). Coronary and myocardial angiography: angiographic assessment of both epicardial and myocardial perfusion. Circulation, 109(25), 3096-3105.

8. Frunza, O., Russo, I., Saxena, A., Shinde, A. V., Humeres, C., Hanif, W., ... \& Frangogiannis, N. G. (2016). Myocardial galectin-3 expression is associated with remodeling of the pressureoverloaded heart and may delay the hypertrophic response without affecting survival, dysfunction, and cardiac fibrosis. The American journal of pathology, 186(5), 1114-1127.

9. Sanchiz-Gomar, F., Perez-Quilis, C., Leischik, R. and Lucia, A., 2016. Epidemiology of coronary heart disease and acute coronary syndrome. Annals of translational medicine, $4^{(13)}$.

10. Weir, R. A., Petrie, C. J., Murphy, C. A., Clements, S., Steedman, T., Miller, A. M., \& McMurray, J. J. (2013). Galectin-3 and Cardiac Function in Survivors of Acute Myocardial InfarctionClinical Perspective. Circulation: Heart Failure, 6(3), $492-$ 498.

11. Gaborit, F., Bosselmann, H., Kistorp, C., Iversen, K., Kumler, T., Gustafsson, F., \& Schou, M. (2016). Galectin 3: association to neurohumoral activity, echocardiographic parameters and renal function in outpatients with heart failure. BMC cardiovascular disorders, $16^{(1)}, 117$.

12. Hamdy, R., Mohamed, L., Abdel-Rahman, T., ElMalah, A., \& Abd-Allah, M. (2014). Clinical and Echocardiographic Correlation of Galectin-3 in Well Defined Heart Failure Patients. $A A M J, 12^{(4)}$. 